考えられ織性の安定したものとは看し得ない。以上よ り完全な織性を得るためには極力經系の織縮を第 67 表 刃は前報(15)式より算出した数值より强性伸長率を゙差 可いた䰚值に近付けるべきて經緯共に潰形を起させ經 系曲線を圆泒の連絰したるのとすべきすのと考えられ る。この事實は經系所要量を減し，且つ探算上孔看過 し得风處で品犋的にる著るしく向上するるのであるか ら極めて重要な點であると考える。 次に緯系の織縮は緯系曲線の方程式より算出すべき であるが獀際上斯かる計算は式が複雜となるから經系 曲線と同樈緯系曲線も圆弧の連續と見做せば經系の織 縮々全〈同樣に算出し得る。從つて前報第 64 表, 第 66 表，第 67 表はそのまま紿糸の織縮を表和すものと なる。而してこの場合名緯系の伸長集を減ずべき雪は 䋑系の場合と同樣であるが緯系の伸長は經系の伸長の 㥞に必ずしる彈性限度以下に限定されずために或る場 合には緯打切れを生じ或る場合には殆ど長伸を起さ ない。普通緯糸の織縮を多くする慗は少くする專に比 し困難なるので經系の場合の樣に糸の太細, 性質, 開 口の時期型式, 經糸の張力等その織法に依り著しく差
を生ずるがら極力織縮率を第 67 表の值限ち前報(15) 式と本報 (4) 式より求めた值仁近付ける樣にすべきす のと考えられる。而して緯系の織縮の大となる織物は 筬立じに開口に依る制約より製造不可能な場合も生じ 斯かる場合は筬打切れを生ずるか或いは製鐡可能な限 度に織性を䢂性にする以外になく斯かる㪇より現在の 織機の性能上の限度子生ずる。

以上より經緯系の織縮を綜合すれば經緯共に潰形を 起させなければ經, 緯何れか一力の織縮は同一でる不 安定な織物となり決して完全な織性は得られない。文 織縮は潰形に依り羑を生じ柔軟な地合のもの程その羑 は大となる。一般に經系織繀は少くなる程, 緯系織縮 は多くなる程普通の織物に於いてはその織性は完全な 子のに近付くこの場合經糸量は減少し緯系量は嘼加す るが普通の織物に於いては織性の完全なるの程經緯合 計の量は滅少するもので探算上も苏めて重要な點と考 えられる。

交献

荻原清, 經緯禾の收縮, 京都高工初 10 年成績報告

(炤和 28 年 5 月 13 日受理)

\title{
繊維及び繊維製品の曲げかたさ
}

\section{II. 布の曲げかたさ}

京都大學工學部 瀻踓化學较室
小野木重治・安藤 昭三

\section{1. 要旨}

前報りに述べた振動りード法が布の曲げかた さの剆定法としても有用であることを確め，澱

粉糊が布の曲げかたさに及に゙す影響を檢討した。 一方簡單な裝置で簡便に布の曲げかたさを测定

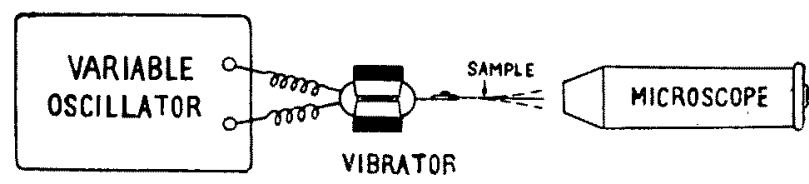

Fig. 1. Schematic diagram of a vibrating a pparatus. 測定原理は前報に述べた通りで，汥置としては Fig. 1 に示すよ5な從來高分子材料の粘彈性測定に使用し て來た裝置をそのまま使用した1。曲げかたさは前埌 の(3) 式

$$
E I=3.194 \times \rho A \times v_{r^{2}} l^{4}
$$

を使つて簡毠に求められる。忙共振及動数，lは振

\section{2. 提動法による測定}




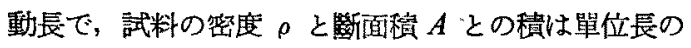
質最に相當する。

先ず数種の布に就いて行つた豫借簤驗の測定佟件及 び結果を第 1 表に示す。試料の楅は何れる $1 \mathrm{~cm}$ にし た。從つて任意の幅に對する曲げかたさはこの表の EIの值に幅(cm で表した)を掛ければよい。なお何れ の場合にる經系の方向定試料片の長さの方向として選 んだ。

第1表 振動法に依る布のかたさの測定

\begin{tabular}{|c|c|c|c|c|}
\hline 試 & $\begin{array}{c}\text { 單位長 } \\
\text { の筫量 } \\
\text { mg } \\
\text { mg }\end{array}$ & $\begin{array}{c}\text { 振動長 } \\
\text { cm }\end{array}$ & $\begin{array}{c}\text { 共振 } \\
\text { 々動数 } \\
\text { cps } \\
\end{array}$ & $\begin{array}{c}\text { 曲げか十 } \\
\text { さ, } E l \\
\text { dynes. } \\
\text { cm }^{2}\end{array}$ \\
\hline 金巾滤布 & 7.43 & 1.01 & 77.0 & $1.46 \cdot 10^{2}$ \\
\hline スフモスA & 10.50 & 1.44 & 37.5 & $2.03 \cdot 11$ \\
\hline スフモスB & 8.79 & 1.47 & 40.0 & $2.10 \cdot / /$ \\
\hline 廐及夕ミ緣 & 21.23 & 2.48 & 43.0 & $47.4 \cdot / 1$ \\
\hline
\end{tabular}

前に述べた菜軟劑の場合とは逆に，糊劑で系又は布 を加工すれば，構成成分である單繊維及び糸は相互に 接着されて動き難くなり，かたさを增大すると考えら れる。これと類似の現象は種々の加工工程に於いて焦

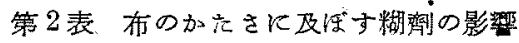

\begin{tabular}{|c|c|c|c|}
\hline 試 料 & $\begin{array}{c}\text { 糊附着量 } \\
\%\end{array}$ & $\begin{array}{c}\text { 單位長の質量 } \\
\text { mg }\end{array}$ & $\begin{array}{c}E I \cdot 10^{-2} \\
\text { dynes } \mathrm{cm}^{2}\end{array}$ \\
\hline 1 & 0 & 19.07 & 6.76 \\
\hline 2 & 1.21 & 19.30 & 8.57 \\
\hline 3 & 2.20 & 19.49 & 13.68 \\
\hline 4 & 3.51 & 19.70 & 33.78 \\
\hline 5 & 5.77 & 20.17 & 70.48 \\
\hline
\end{tabular}

Fig. 2. Effect of starch on the flexural rigidity of a cloth sample.

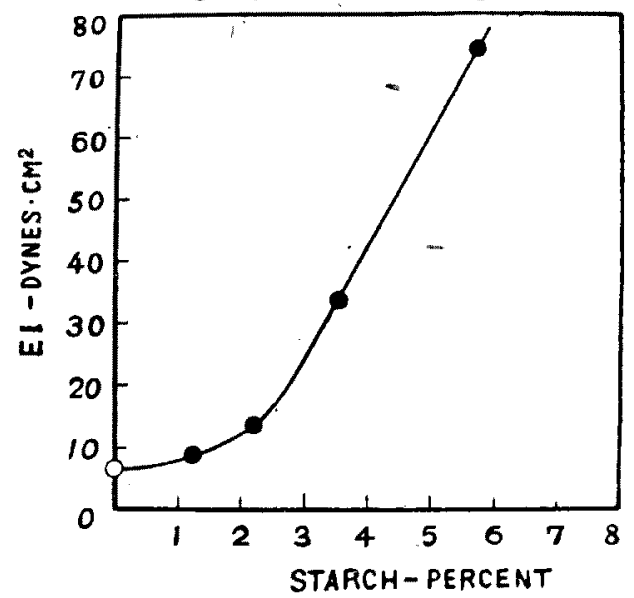

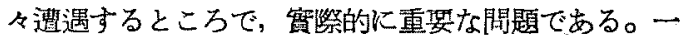
例として激粉糊で加工した布のかたさを測定した結果 を第 2 表及び Fig. 2. と示す。

試料は何孔も同一の布で附着澱枌量が買るだけであ

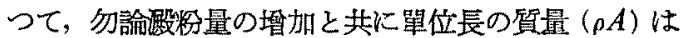

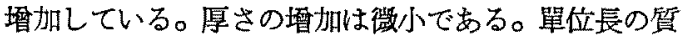
量及び厚さが增加すれば，何れの場合にもかたさは增 加するのであるが，今の場合兩者の堌加は極めて少い ので，そのかたさに與克る效果は㱠んぞ無視される。

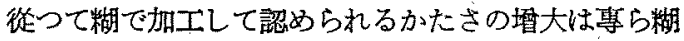
による接着效果に餙ずることが出來る。

\section{Clark 型柔軟度試驗機による測定}

Clark paper softness tester は米國に於いて紙のか たさの測定の規格2にになつている試驗機で2,3,4)，平行 に並んだ2個のローラの間に適當な長さの試料を挾み， 2 つのローラをその接線を軸として迴轉させ，迴轉角 を指釬及び目盛板によつて藖み取れるような構造を有 している。一方へ迴轉して試料が反轉する時の角度を 顠み，次に逆に迴轉して再び試料が反轉する角度を讀 む。これら丽迴轉角の和が $90^{\circ} \pm 2^{\circ}$ (これを踾界角と呼 ぶ）になる長さ $L$ (これを臨界長と言う）を決定して, これを諸種の彈性的性質と關係がける。例えば曲げか たさに比例する量としては，この $L$ の 3 乘と單位面 積虽りの質量 $W$ との㮩に一定の定數 (10-4) を掛け, これを“Rigidity”と定義している。

我々の試作した特置の前面圖を Fig. 3 に示す。 この裝置を使用して数種の布に就いて㵋定した結果

Fig. 3. Front view of the softness tester of Clark type.

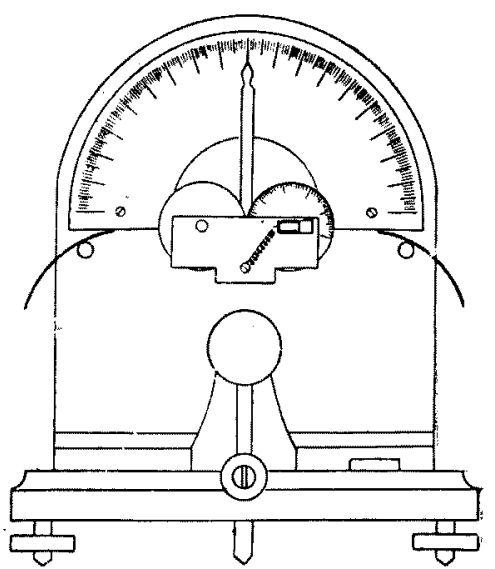


第 3 表 クラーク型試驗機で測定した布のかたさ

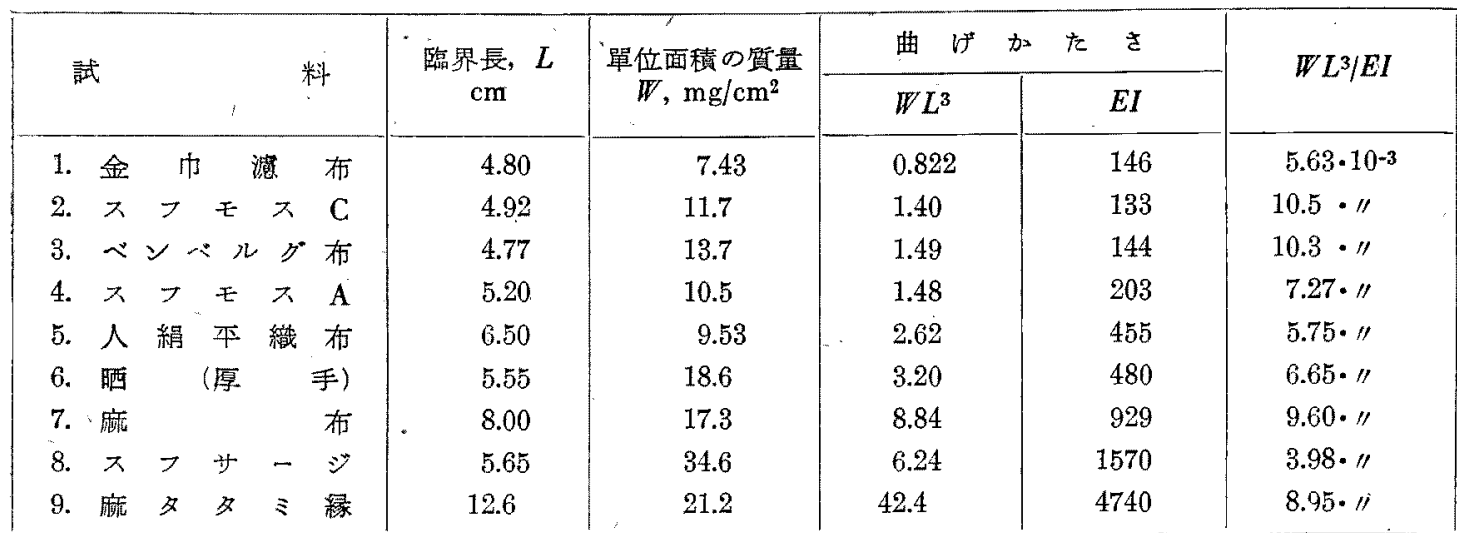

を，振動法で測定した曲げかたさ（EI）と比較すると 第 3 表の通りである。な敃試料は何れる縦方向を長さ の方向とし, Clark 型試驗㙨で測定する時の幅は $2 \mathrm{~cm}$ にした。

これらの結果を見れば，大體に於いて㗏動法で得ら れる曲げかたさの大きいるの程 Clark型試驗機で測定 されるかたさ $W L^{3}$ (この值はかたさの相對值に過ぎな い) 更大きいが，雨者が全くは比例していないことが 制る。郎ち $W L^{3}$ と $E I$ との比は一定ではなく，布に

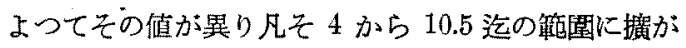
つている。しかるそれらの間には何等の規則性も見出 乙得ない。しかし全體として眺めると，かたさが非常 《相赸している割合にはこれらの比の值の相違は趛か に小さく，WL かかたさを可成り忠曾に表している るのであることを示唆している。兩湘定値の間に完全 な比例性の成立しないのは, 恐らく兩種の則定間に存 在する本質的な佟件の相逜の影響が布の種類によつて 異ることに因るすのと考兵られる。さらに今一つの根 本的問題として，Clark の方法はかたさ及び臨界長を 異にする試料がすざて變形の臨界㥈に於いて幾何學的 に類似の形狀を有する時にのみ正しい比較可能な結果 が得られるのでめつて，紙に關してはこの形狀の類似 性の存在が確認されたと報告されている4)。我々の布 の場合にはこの點に就いての吟味はなされていないが， 恐らく相當程度この幾何學的類似性が存在し，嚴波な 類似性の成立は保登されないものであろう。

次に臨界長 $L$ の決定に際し, 長さを色々警えて迴 轉角か门度 $90^{\circ} \pm 2^{\circ}$ の臨界任に相當する點を決定する のは手数を姴するので，紙㳅就いては簡便な決定法が 示されている。郎ち先ず $90^{\circ}$ より小さい或る迴轉佳 $\alpha_{1}$ に相當する長さ $L_{1}$ を求め，次に $90^{\circ}$ より大きい或 る角に $\alpha_{2}$ 相當する長さ $L_{2}$ を求め, 次式を使つて $90^{\circ}$ に相當する臨界長 $L$ を計算する。

$$
L=\frac{\left(90-\alpha_{1}\right)\left(L_{2}-L_{1}\right)}{\left(\alpha_{2}-\alpha_{1}\right)}+L_{1}
$$

この式の適用出來るのは, 明か比迴轉角と長さとの 間に比例關係の存在する場合であつて, 多種の紙に就 いてこの比例性が確認されている。二，三の布に就い てこの比例性を檢討したが，Fig. 4 のように美しい直 線關係が得られだ。從つて布の場合にる上式を使用し て臨界長 $L$ を決定することが可能である。このように 布の場合にも紙に於けるのと類似の擧動が蒦察される 罗蒀は Clark の方法の布試驗に對する適用性を支持す るものである。

Fig. 4. Relationship between critical length and angle of rotation.

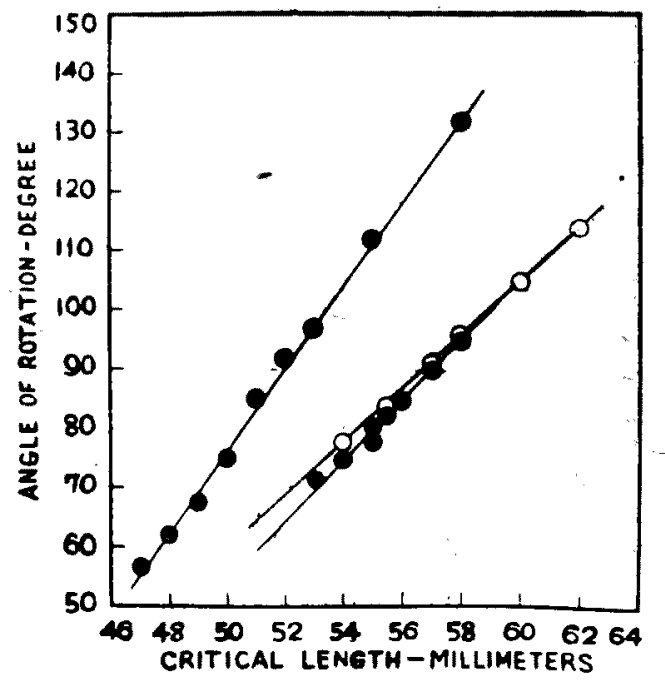




\section{4. 總 括}

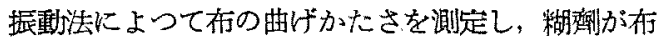
のかたさに及ぼす影響を检討した。

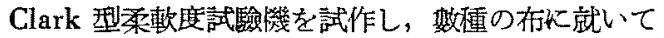
この試䠼機を用いて測定したかたさと振動法で測定し たかたさとを比校した。雨测定值の閒には比較的良好 な此例性が存在する。また迴轉角と長さとの間には良 好な直線關保の成立寸ることが㰣つた。これらの默を 考慮して Clark 型試驗譏は㭛の試驗にも充分道用可能 と考光られる。

振動法による結果と Clark 法による結果とが敂密に 比例しない理由として二，三の根本的な事項を擧げる ことが出來る。實際問題として何れの方法がより合目 ”的であるかは速斷出來ない。
本研究の大牛は昭和 26 年 5 月繊維學會關西支部年 會に㘮て發表し，その後幾分データを補足した。最後

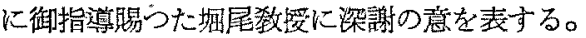

\section{- 文献}

1) Horio, Onogi, Nakayama, Yamamoto; J. Applied Phys., 22 $r=966$ (1951)

2) TAPPI Tentative Standard T451 m44, Paper Trade J., 121, No. 20: 31 (1945); ibid., 111, No. $22: 123$ (1940).

3) J. d'A Clark; Paper Trade J., 100, No. 13: 41 . (1935).

4) Institute of Paper Chemistry; Paper Trade J., 110 , No. $7: 29$ (1940).

5) 小野木, 安藤; 本誌, 9, 12, 617 (1953)

（昭和 24 年 5 月 9 日受理）

\section{絹フィブロインのアルカリ溶解度測定を提唱する}

信州大學繊維學部 奥 正 巳・清 水 周

天然絹絲の本質を諭ずるに際し絹フィブロインの耐 アルカリ性，而豉潤性をしらべる事は極るて肚姴であ るが，琖合乍ら今日迄滴當な方法か鹪ぜられなかつた 事は遺澸である。著者は天然絹絲の化學的强化欧善に 關する研究の途上どうしてい耐了ルカリ性をしらべる 必要に迫られて色々な方法を譜じて見たが，結局アれ カリ溶解度を測定するのが最も簡便で且つ最も應用範 圍の廣い方法である事を知つたので新にナルカリ溶解 度測定を提唱して今後の活用を期待するるのである。

絹と同し動物性蛋白繊維である羊毛の耐アルカリ性 をしらべるのに矢張りアルカリ溶解度を測定する方法 が Harris 氏1)等によつて實推せられて相當活用籍園 の庶い方法である事が㙺證せられて來たが著者は絹の

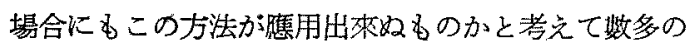
翼驗を行い又現在も行いつつあるが，極めて適當な方 法である青を知り得た次第である。

\section{1. アルカリ溶解度測定法}

踭め閣係瀑度 $65 \%$ の空氣中に放置して一定の濕分 を含有せしめた絹フィブロイン約 $1 \mathrm{~g}$ を精密に科量し 之れを豫め $65^{\circ} \mathrm{C}$ に昇溫せしめた $0.1 \mathrm{~N} \mathrm{NaOH}$ 溶液
（浴比 1:100）中に投入して精確に 1 時間處理した後吸 引溜過し水洗乾燥し，關係湶度 $65 \%$ の空氣中に放置 して科量し重量の減少率を以つて絹フィブロインのア ルカリ溶解度とした。測定裝置としては菇者の 1 人

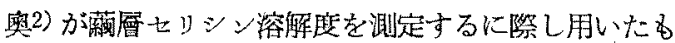
ので恒溫グリセリン浴中に迹流冷却器を附せる內容的 $300 \mathrm{cc}$ の薏沸フラスッを用いた。

\section{2. 絹フィブロインのアルカリ溶解度測定例}

著者の得た絹フィブロインのアルカリ溶解度測定成 綂憎著が目下從事中の絹の化學的强化改善に關する 研究中に多數あるが之等に關してはやがて相次で登表

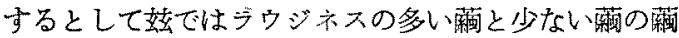
層の部位別による絹フ、ブロインのアルカり溶解㽻の 差買をしらべて興珠ある結果を得たのでその一例のみ を掍げるに止めておく。ラウジネフの多い荡，少ない

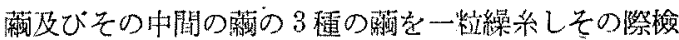

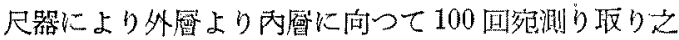

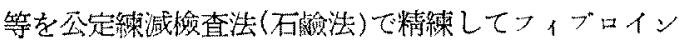

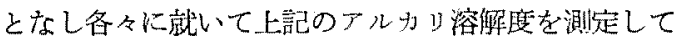
第 1 表の如き結果を得た。 